\title{
REDUCTION OF AMMONIA EMISSIONS FROM CATTLE MANURE USING BIOPREPARATIONS
}

Rolandas BLEIZGYS, Dr., Prof., Institute of Energy and Biotechnology Engineering, Aleksandras Stulginskis University. Research interests: technologies and housing systems for animal husbandry. Address: Studentu str. 11, Akademija, LT-53361 Akademija, Kaunas r., Lithuania. E-mail: rolandas.bleizgys@asu.lt

Reda MAŽEIKIENĖ, PhD., Institute of Energy and Biotechnology Engineering, Aleksandras Stulginskis University. Research interests: air pollution control in animal husbandry. Address: Studentu str. 11, Akademija, LT-53361 Akademija, Kaunas r., Lithuania. E-mail: reda.mazeikiene@asu.lt (corresponding author)

Experimental studies performed at the laboratory enabled to find out the effect of the biopreparation on the process of ammonia volatilization from manure. Adding biopreparation to manure was found to slow down ammonia emission from manure. Depending on the manure composition, temperature of the environment, and duration of exposure to the biopreparation, the emission was found to decrease by up to $22 \%$. The maximum effect was observed on the day 6-14, whereas 30 days after biopreparation's use its effect was significantly decreased. The effect of biopreparation on ammonia volatilization was observed to be higher under more intensive ammonia emissions, i.e. when the manure was fresh, with no crust formed on its surface, under high air flow velocity above the manure and high ammonia concentration gradient in the surface of the manure. Use of the biopreparation is highly recommended for reduction of ammonia emissions in litter-free barns where liquid manure accumulates. Its use is consistent with the modernization tendencies to implement litter-free liquid manure technologies.

Keywords: $\mathrm{NH}_{3}$ emissions, manure, cowsheds, biopreparations

\section{INTRODUCTION}

Considerable intensification of livestock production leads to the increased concentration of emissions at the sites of livestock farming. High amounts of emissions containing air pollutants such as ammonia $\left(\mathrm{NH}_{3}\right)$, hydrogen sulphide, mercaptans, etc., not only are known to cause animal diseases but also lead to health disorders of operators and other persons residing in the surrounding areas as well as present a threat to the surrounding environment. Environmental issues at the sites of intensive livestock farming are becoming increasingly important. Recently, farms have been significantly increasing in size, and automated, open and naturally ventilated dairy barns have gained popularity despite the fact that they are characterised by many factors that lead to increased $\mathrm{NH}_{3}$ emissions. Among other these might include high temperatures in barns, high amounts of liquid manure are accumulated, animals are kept inside the barn all year round, etc. Most of the European countries (where the numbers of animals are not decreasing) are not fulfilling their international obligations to reduce $\mathrm{NH}_{3}$ emissions. Ammonia emissions is becoming a significant issue at the international level, meanwhile livestock production accounts for more than $90 \%$ of total $\mathrm{NH}_{3}$ emission.

Problems related to the $\mathrm{NH}_{3}$ emission is even further aggravated by the rapid spread of technologies of keeping the cattle in cold, open and naturally ventilated barns. In such barns, factors of the microclimate are highly influenced by weather conditions that become increasingly variable and less predictable. Naturally ventilated cattle barns pose many methodical issues for the analysis of gas emissions, no precise methods for measuring the gas spread are available, the ventilation rate is difficult to be found (Teye et al., 2008; Kaasik et al., 2013; Bleizgys et al., 2013). Researchers that have studied the microclimate in barns of this particular type have found that processes of $\mathrm{NH}_{3}$ emissions and air pollution are difficult to control there (Bjerg et al., 2013; Rzeznik et al., 2016; Samer et al., 2012; Pereira et al., 2014; Mendes et al., 2015; Zhao et al., 2007).

Ammonia emissions can be reduced by controlling thermal processes. Ammonia concentration in barns is most significantly influenced by the temperatures and intensity of air movement (Wu et al., 2012; Rong et al., 2009; Bleizgys et al., 2014). Proper management of air temperatures can significantly decrease ammonia volatilization from manure (Pereira et al., 2012). Ammonia is released from manure in result of urease activity which is in turn influenced by the temperature of manure, whereas the latter is highly depended on the air temperature. Temperature rise causes activity of

Copyright (C) 2017 The Authors. Published by Aleksandras Stulginskis University. This is an open-access article distributed under the terms of the Creative Commons Attribution License (CC-BY 4.0), which permits unrestricted use, distribution, and reproduction in any medium, provided the original author and source are credited. 
urease to increase while at the same time leading to increased ammonia emissions from manure (Moreira et al., 2006; Ngwabie et al., 2011). A high temperature of the manure increases the formation of aqueous ammonia in the manure and the formation of gaseous ammonia, while decreasing the solubility of ammonia in water. Evaporation of water from manure causes concentration of ammonia to increase. When the air-borne concentration of ammonia is below the concentration of ammonia above the surface of manure, an intensive ammonia volatilization occurs. Reduction in the intensity of ammonia volatilization is well achieved by means of controlling thermal processes within a barn and reducing air temperature (which is particularly important under temperatures above $20^{\circ} \mathrm{C}$ ). Decreasing the average annual air temperature $\left(11.3{ }^{\circ} \mathrm{C}\right)$ by one degree in a semi-warm box-type dairy barn, $\mathrm{NH}_{3}$ emission is observed to decrease by $10 \%$ (Bleizgys et al., 2016). As the ventilation rate is increased, the concentration of ammonia decreases in a barn whereas, $\mathrm{NH}_{3}$ emission is observed to increase disproportionally (Philippe et al., 2011; Samer et al., 2012). Reduction of air circulation inside dairy barns presents a good potential to reduce atmospheric pollution with ammonia gas from them (Bagdonienè et al., 2014).

However, the potential of reducing air pollution from open, naturally ventilated dairy barns by controlling thermal processes inside them is very limited. In result of cattle farming more than $50 \%$ of ammonia is released to the environment, however researchers unanimously recognise that effective measures to control air pollution from open, naturally ventilated dairy barns have not been developed yet. Ammonia volatilization from the surface of manure into the environment represents a complex process (Philippe et al., 2011). These processes are difficult to control due to constant variation of many factors involved. Variation in air velocity, turbulence and temperature will cause the $\mathrm{NH}_{3} \mathrm{emission} \mathrm{to}$ vary too (Rong et al., 2009; Saha et al., 2010). The crust that forms on the surface of the manure has also a significant effect on variation in $\mathrm{NH}_{3}$ emission. Its formation is significantly determined by the dry matter content of manure and climatic conditions (Aguerre et al., 2012).

The process of ammonia volatilization is influenced by many factors such as temperature, air humidity, air velocity, protein content of the manure, moisture content of the manure, $\mathrm{pH}$, etc. Ammonia volatilization occurs in every stage of manure origin, storage and spreading: approx. $37 \%$ of total ammonia emissions occur in barns, $20 \%$ - from manure heaps, $38 \%$ - from manure spreading, and the rest $5 \%$ - from cattle grazing. In order to reduce air pollution the factors that influence the process of ammonia volatilization must be taken under control in every stage of manure handling: starting with an animal kept in a barn and ending with manure insertion into to soil. This is a difficult and complicated task which leads to search for innovative measures to reduce $\mathrm{NH}_{3}$ emission and implementation thereof in technologies of livestock keeping in open and naturally ventilated barns. Solutions are sought for using biopreparations that aid in reducing the intensity of ammonia volatilization from manure (Matusiak et al., 2015). It is highly important to optimize the conditions of biopreparations' use that are consistent with the type of animal keeping, technological factors of microclimate and manure handling.

The objective of the study was to examine the effects of the biopreparation on ammonia volatilization from manure and to assess the potential of controlling and reducing $\mathrm{NH}_{3}$ emissions from barns by using biotechnological techniques.

\section{OBJECTS AND METHODS}

Experimental tests have been carried out at the Laboratory of Thermal Energetic Processes and Emissions of Aleksandras Stulginskis University. For the purpose of tests a fresh liquid livestock manure was used. Prior to testing manure was homogenized - a manure collected at the box-type cowshed was placed into the large container and mixed. Afterwards, the manure of homogeneous composition was transferred to 2 containers of 301 each; the first container was used to store manure with the biopreparation (Bacillus subtilis; Bacillus licheniformis; Bacillus amyloliquefaciens) added, and the second one - to store the manure free of any biopreparations (control container). The manure stored in the first container is periodically added with the biopreparation and thoroughly mixed. Prior to adding the biopreparation (6 gr.) is dissolved in water $(150 \mathrm{ml})$.

Experimental tests are carried out to assess the process of ammonia volatilization from the manure free of any additives and from the manure with the biopreparation added. Comparative analysis of gas emissions from manure were carried out in the test rig shown in Fig. 1 where simulating the conditions present in dairy barns the process of ammonia volatilization from manure was analyzed. To examine the intensity of gas emission a mass flow technique was used. At the given intensity of wind tunnel ventilation $G\left(\mathrm{~m}^{3} \cdot \mathrm{h}^{-1}\right)$ and gas concentration in the air entering the tunnel $C_{e}\left(\mathrm{mg} \mathrm{m}^{-3}\right)$ and in the air being removed from tunnel $C_{o}$, the intensity of gas emission $\mathrm{E}_{\mathrm{NH} 3}\left(\mathrm{mg} \cdot \mathrm{m}^{-2} \cdot \mathrm{h}^{-1}\right)$ is calculated as follows:

$$
E_{\mathrm{NH}_{3}}=\left(C_{o}-C_{e}\right) G
$$

The following factors influencing ammonia volatilization from manure were kept constant: temperature, air flow above the manure. After placing the manure in the drawer-chamber (3) inside the wind tunnel, the ventilator (11) was turned-on and testing was started. A directional air flow occurs above the manure. The manure from the first container is placed in the wind tunnel, emission testing is accomplished and manure is returned back to the first container. The researches lasted for 70 days. Afterwards, the same testing is done with the manure from the second container. Each test is repeated for 4-5 times. With the manure stored in containers, tests are carried out periodically every 6-8 days. 


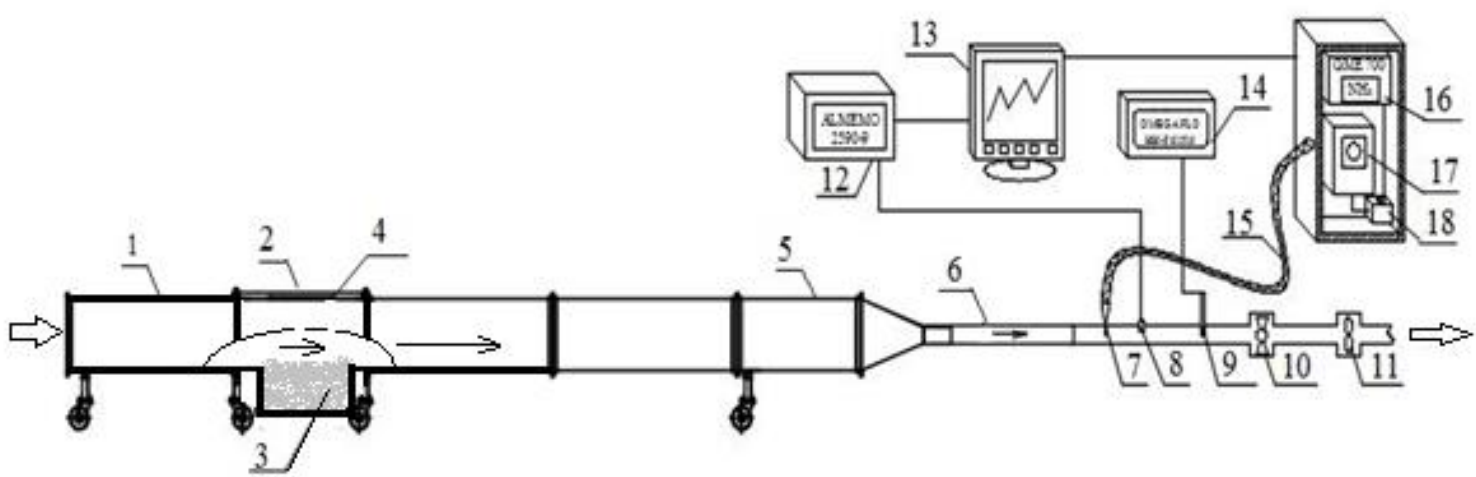

Figure 1. The schematic view of ammonia emission from manure inside the wind tunnel: 1 - housing of a wind tunnel (400x400 $\mathrm{mm}) ; 2$ - cover; 3 - "a drawer" for manure storage; 4 - a section for manure storage; 5 - transition cone; 6 - a duct (100 mm in diameter); 7 - air sampling probe; 8 - sensors of temperature and moisture content; 9 - sensor of thermal wind speed indicator; 10 a valve; 11 - a ventilator with a frequency inverter; 12 - a measuring and data storage instrument 'Almemo 2590-9'; 13 - PC (with software AMR); 14 - a wind speed indicator 'OMEGAFLO HH-F615M'; 15 - a heated air intake hose; 16 - laser gas analyser 'GME700'; 17 - electrically heated three-way valves; 18 - a membranous air pump.

The manure is placed in the manure storage chamber (3) and levelled out to comprise a $0.23-0.25 \mathrm{~m}$ thick layer. The chamber containing manure is then inserted into the wind tunnel in the section for manure storage (4). The ventilator (11) is used to suck the air from the wind tunnel while creating a required air flow above the manure surface. The ventilator is fitted in the duct (6) with the diameter of $100 \mathrm{~mm}$. The ventilation rate in the wind tunnel is varied by the valve (10) fitted in the duct (6) by varying the cross-section area of the duct and varying the ventilator revolutions (11) using frequency invertor. Air samples were collected in the duct (6) using probes (7) and fed into the gas analyser (16) using the heated hose (15). Air is continuously supplied to the analyser using a pump (18) with the capacity of $61 / \mathrm{min}$. To prevent air condensation it is pre-heated in the hose (15) and in the electrically heated valves (17) to achieve the temperature of $150^{\circ} \mathrm{C}$. Prior to testing, gas analyser and measuring and data storage instrument 'Almemo 2590-9' (12) are made compatible with each other and pre-programmed to record data at steps of $1 \mathrm{~min}$.

The concentration of ammonia gas $\left(\mathrm{NH}_{3}\right)$ is measured using the analyser GME700 (SICK MAIHAK GmbH, Germany) (16). Its measurement range is $0 \mathrm{ppm}$ to $100 \mathrm{ppm}$, accuracy $\pm 0.5 \mathrm{ppm}$. This particular device uses the principle of measurement of laser spectroscopy. As the analyser features heating of gas being sucked, gas conditioning ensures prevention of pollution and condensation occurrence in the cell. In order to ensure the operational temperature is always above the dew point of the sample, the electrically heated 3-way valves are used. Operating mode: automatic (continuous or cyclic measurement with data storage).

Temperature and moisture content of the air fed to the wind tunnel and removed from it is measured using sensors of temperature and moisture content (8) connected to 'Almemo 2590-9' (Ahlborn GmbH, Germany) within the system (12). Measurement range: temperature $-30 \ldots 60{ }^{\circ} \mathrm{C}$, and relative air humidity $5 \ldots 98 \%$, measurement accuracy of the device $\pm 0.1 \%$. The temperature of manure is measured using temperature sensors - thermocouples. Each thermocouple is made of wires with the diameter of $0.5 \mathrm{~mm}$ covered with moisture resistant insulation. Temperature measurement resolution $0.1^{\circ} \mathrm{C}$. Thermocouples are connected to the measurement and data storage device 'Almemo 2590 - 9' (Ahlborn GmbH, Germany).

A wind speed indicator 'OMEGAFLO HH-F615M' (Omega, USA) (14) is used to measure air velocity which is further converted into air flow rate. Measurement range: $0-30 \mathrm{~m} \mathrm{~s}^{-1}$, accuracy $\pm 0.1 \mathrm{~m} \mathrm{~s}^{-1}$.

Analysis of experimental data enabled to calculate arithmetic means of parameters and their standard errors. The statistical data reliability was assessed based on the Student's criterion. The threshold of difference between standard error and confidence level was calculated at the statistical significance level of $\mathrm{p}<0.05$.

\section{RESULTS AND DISCUSSION}

Experimental testing was performed on the fresh cattle manure containing $6.84 \pm 0.09 \%$ of dry matter. The ventilation rate above the manure inside the wind tunnel varied from 2.83 to $19.78 \mathrm{~m}^{3} \mathrm{~h}^{-1}$ or when converted to the ventilation rate per single square meter of the manure surface, varied from 13.46 to $94.20 \mathrm{~m}^{3} \mathrm{~h}^{-1} \mathrm{~m}^{-2}$. The temperature was kept constant at $19.7 \pm 0.63{ }^{\circ} \mathrm{C}$, which corresponds to the average temperature normally present inside dairy barns in summer times. Manure was stored for total 70 days in both open containers, and mixed periodically. The biopreparation was added to the first container at the beginning of the experimental testing, and afterwards on days 14, 22, 301, 58 and 62. After taking out of storage container the manure was placed in the wind tunnel, and ammonia emission from it was measured on the first day and then on days $6,14,22,30,38,58,70$. Fig. 2 shows the variation in concentration of ammonia inside the wind tunnel on days 14,38 and 70. Ammonia concentration was observed to reach a steady state and afterwards vary only insignificantly after $20-30 \mathrm{~min}$. This is the time period needed for stabilization of the ammonia volatilization from manure. The process of gas volatilization from the manure containing biopreparation under consideration was observed to be more stable, however. Comparison and assessment of the ammonia emission rates from different manures 
requires for the analysis of not instantaneous values of emission but mean values calculated for 30 min. period from the start of the test.

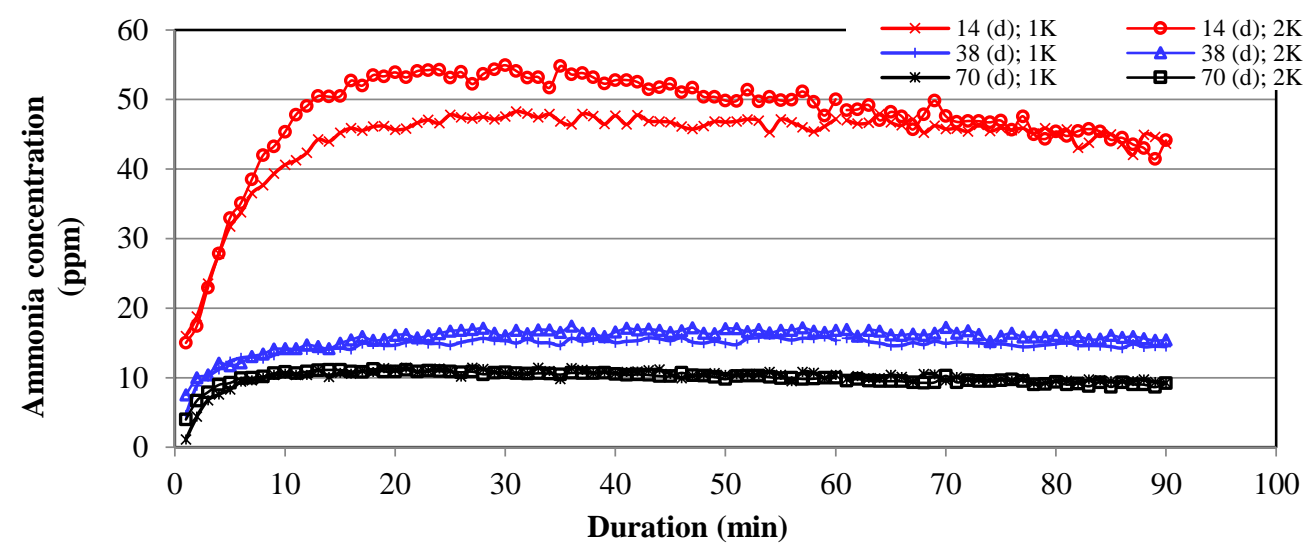

Figure 2. Variation in concentration of ammonia inside the wind tunnel filled with the manure: $1 \mathrm{~K}$ - manure containing the biopreparation; $2 \mathrm{~K}$ - manure free of any additives. $\mathrm{d}$ - duration of manure storage in days.

In a course of manure storage its ammonia emission was observed to decrease. At the beginning of experimental testing, ammonia emission from the manure containing the biopreparation and the manure free of any additives was observed to be very similar. In both cases mean concentrations of ammonia over the period of 30 min. inside the wind tunnel differed up to $0.6 \%$, no significant differences were found (see Fig. 3). After several days the effect of biopreparation on ammonia volatilization from manure becomes evident. In a course of storage of manure containing the biopreparation, ammonia emission is observed to decrease at a higher rate than that of the manure free of any additives.

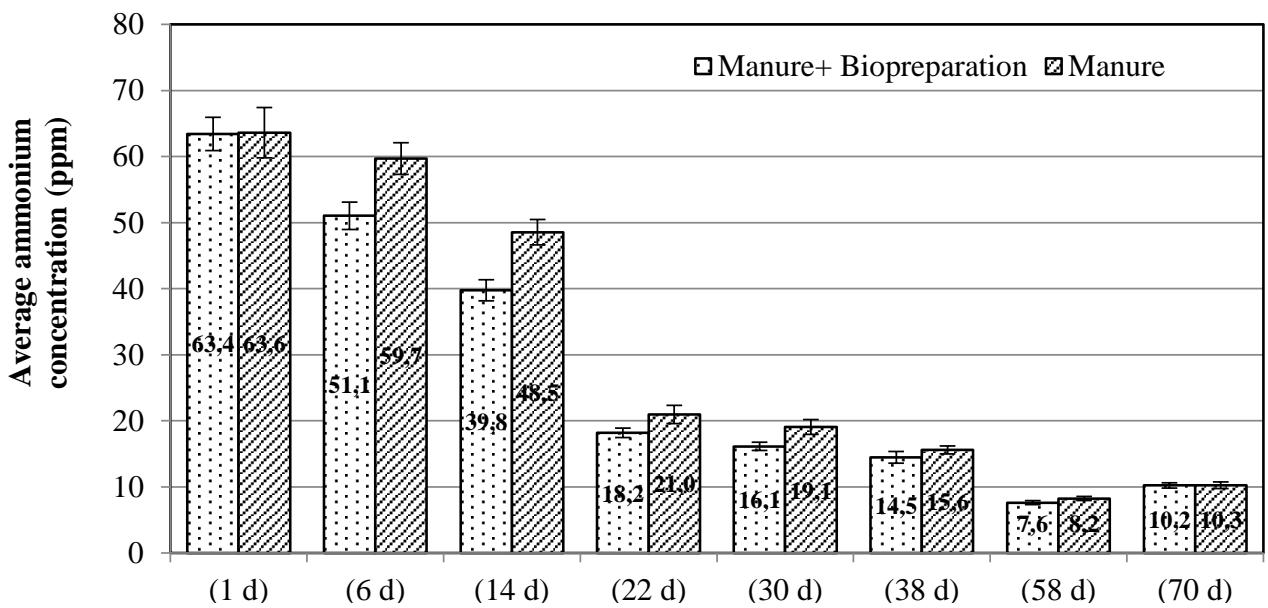

Figure 3. Mean ammonia concentrations inside the wind tunnel (over the period of $30 \mathrm{~min}$.), filled with manure containing the biopreparation or manure free of any additives.

In a course of the experimental testing, the rate of air flow above the manure was increased while ensuring more favourable conditions for ammonia volatilization at a higher rate. Before the day 30 of experimental testing, the ventilation rate was $13.5 \mathrm{~m}^{3} \mathrm{~h}^{-1} \mathrm{~m}^{-2}$, on day $38-28.3 \mathrm{~m}^{3} \mathrm{~h}^{-1} \mathrm{~m}^{-2}$, and on days 58 and $70-94.2 \mathrm{~m}^{3} \mathrm{~h}^{-1} \mathrm{~m}^{-2}$. The effect of the biopreparation on ammonia volatilization rate was found to be greater under higher ventilation rates above the manure.

The maximum difference between ammonia concentrations was found on days 6 and 14; afterwards it was observed to decrease. Regardless of the continuous use of the biopreparation, on the day 70 the difference was already insignificant (see Fig. 4). 


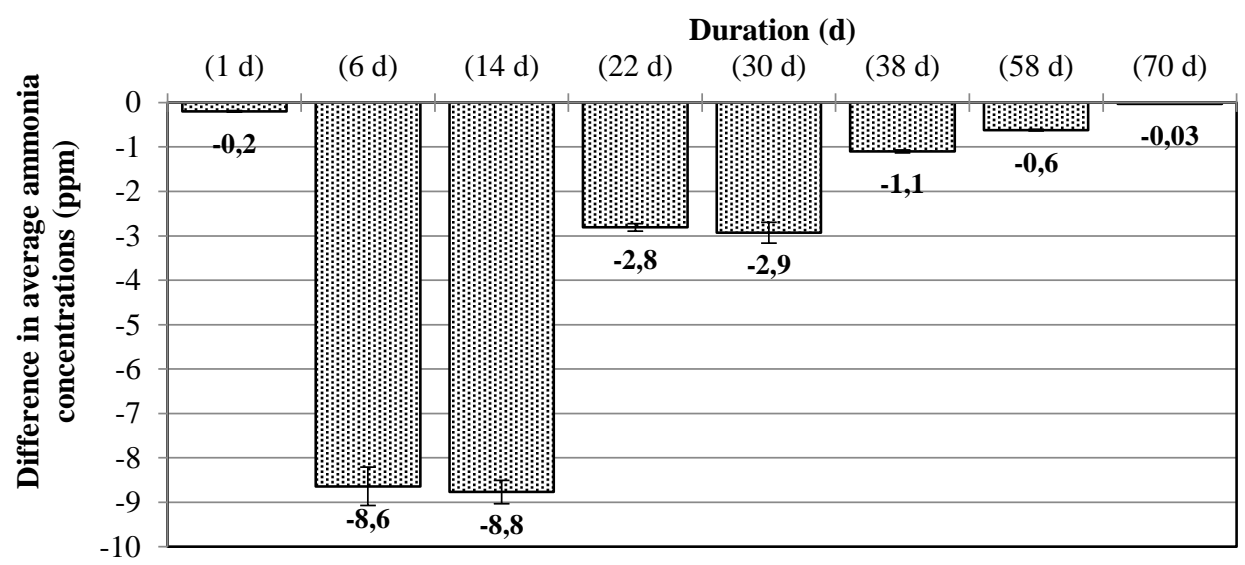

Figure 4. Decrease in the average (over period of $30 \mathrm{~min}$.) ammonia concentrations inside the wind tunnel with the manure containing the biopreparation in comparison to the manure free of any additives.

Ammonia volatilization from manure containing the biopreparation was found to decrease at higher rate. The effect of the biopreparation was observed to be different every day (see Fig. 5.). The maximum effect was recorded on day 14, with the ammonia emission being lower by $22 \%$. Later on after this particular day the tendency of decreasing effect was observed: on day $22-15 \%$; on day $38-7 \%$. On day 58, the effect on emission was found to increase again: ammonia emission from manure containing the biopreparation was by $8 \%$ lower than that from manure free of any additives. This is associated with the increase in ventilation rate and intensified ammonia volatilization.

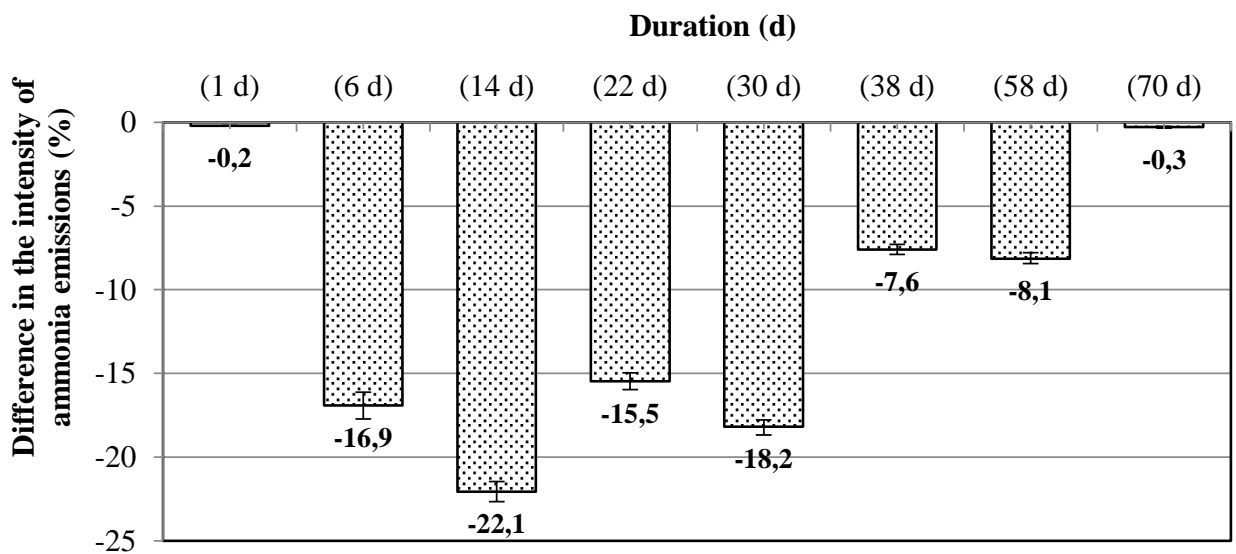

Figure 5. Decrease in ammonia emission from manure containing the biopreparation in comparison to the emission from manure free of any additives.

Adding biopreparation to the manure causes the rate of ammonia emission to decrease. The effect of biopreparation on ammonia volatilization was found to be more pronounced under higher rates of ammonia emissions, i.e. when manure was fresh, no crust formed on the surface of manure, at higher air flow above manure and high ammonia concentration gradient in the surface of the manure.

Problems associated with the air pollution by ammonia gas is best to be solved using integrated means by controlling thermal environment, and when the weather temperature rises - by using biopreparations.

\section{CONCLUSIONS}

The process of ammonia emission from manure is highly complicated and influenced by many factors such as temperature, air humidity, air velocity, protein content of manure, moisture content of manure, $\mathrm{pH}$, rate of water evaporation from manure, etc. Consequently these factors must be taken into consideration when analysing the effect of biopreparation on the ammonia volatilization from manure.

The biopreparation has a certain effect on the process of ammonia volatilization from manure. Adding biopreparation to the manure causes the rate of ammonia emission from it to decrease. Depending on the manure composition, temperature of the environment, and duration of exposure to the biopreparation, the emission decreases by up to $22 \%$. The maximum effect is observed on days 6-14, whereas 30 days after the biopreparation's use its effect is significantly decreased. The effect of biopreparation on ammonia volatilization is higher under more intensive ammonia emissions, i.e. when the manure is fresh, with no crust formed on its surface, under high air flow velocity above the manure and high ammonia concentration gradient in the surface of the manure. 
Use of the biopreparation is highly recommended for the reduction of ammonia emissions in dairy barns free of litter where liquid manure is being accumulated. Its use is consistent with the modernization tendencies to implement litter-free liquid manure technologies.

To increase the efficiency of use of biological preparations it is necessary to accomplish more comprehensive experimental researches while taking into consideration the influence of different parameters on the processes of interaction between manure and biopreparations.

\section{REFERENCES}

1. Aguerre, M.J., Wattiaux, M.A., Powell, J.M. 2012. Emissions of ammonia, nitrous oxide, methane, and carbon dioxide during storage of dairy cow manure as affected by dietary forage-to-concentrate ratio and crust formation. Journal of Dairy Science, Vol. 95, Iss. 12, pp. 7409-7416.https://doi.org/10.3168/jds.2012-5340

2. Bjerg, B., Cascone, G., Lee, I.B., Bartzanas, T., Norton, T., Hong, S.W., Seo, I.H., Banhazi, T., Liberati, P., Marucci, A., Zhang, G. 2013. Modelling of ammonia emissions from naturally ventilated livestock buildings. Biosystems Engineering, Vol. 116, Iss. 3, pp. 259-275.https://doi.org/10.1016/j.biosystemseng.2013.06.012

3. Bagdonienè, I., Bleizgys, R. 2014. Ammonia emissions from dairy cattle manure under variable ventilation rates. Annals of animal science, Vol. 14, Iss. 1, pp. 141-151.https://doi.org/10.2478/aoas-2013-0084

4. Bleizgys, R., Bagdoniene, I. 2016. Control of ammonia air pollution through the management of thermal processes in cowsheds. Science of the Total Environment, Vol. 568, pp. 990-997.https://doi.org/10.1016/j.scitotenv.2016.05.017

5. Bleizgys, R., Čèsna, J. 2013. Research of Microclimate in Dairy Cattle and Pig Buildings. Proceedings of the International Scientific Conference "Rural development 2013“, Vol. 6, Book 3, pp. 20-24.

6. Bleizgys, R., Baležentienè, L. 2014. Assessments of biogenic gas emission procesess in cowsheds. Polish Journal of Environmental Studies, Vol. 23, Iss. 4, pp. 1107-1114.

7. Kaasik, A., Maasikmets, M. 2013. Concentrations of airborne particulate matter, ammonia and carbon dioxide in large scale uninsulated loose housing cowsheds in Estonia. Biosystems engineering, Vol. 114, pp. $223-231$. https://doi.org/10.1016/j.biosystemseng.2013.01.002

8. Matusiak, K., Borowski, S., Opalinski, S., Bakula, T., Kolacz, R., Gutarowska, B. 2015. Impact of a microbial-mineral biopreparation on microbial community and deodorization pf manures. Acta Biochimica Polonica, Vol. 62, Iss. 4, pp. $791-798$. https://doi.org/10.18388/abp.2015_1135

9. Mendes, L.B., Edouard, N., Ogink, N.W.M., C. van Dooren, H.J., Tinoco, I.F.F., Mosquera, J. 2015. Spatial variability of mixing ratios of ammonia and tracer gases in a naturally ventilated dairy cow barn. Biosystems engineering, Vol. 129, pp. 360-369. https://doi.org/10.1016/j.biosystemseng.2014.11.011

10. Moreira, V.R., Satter, L. 2006. D. Effect of scraping frequency in a freestall barn on volatile nitrogen loss from dairy manure. J Journal of Dairy Science, Vol. 89, pp. 2579-2587.https://doi.org/10.3168/jds.S0022-0302(06)72334-7

11. Ngwabie, N.M., Jeppsson, K.H., Gustafsson, G., Nimmermark, S. 2011. Effects of animal activity and air temperature on methane and ammonia emissions from a naturally ventilated building for dairy cows. Atmospheric Environment, Vol. 45, Iss. 37, pp. 67606768.https://doi.org/10.1016/j.atmosenv.2011.08.027

12. Pereira, J., et al. 2012. Effects of temperature and dairy cattle excreta characteristics on potential ammonia and greenhouse gas emissions from housing: A laboratory study. Biosystems Engineering, Vol. 112, Iss. 2, pp. $138-150$. https://doi.org/10.1016/j.biosystemseng.2012.03.011

13. Pereira, J., Trindade, H. 2014. Control of ammonia emissions in naturally ventilated dairy cattle facilities in Portugal. The Engenharia Agricola Journal. Vol. 34, Iss. 3, pp. 600-609. https://doi.org/10.1590/S0100-69162014000300022

14. Philippe, F., Cabaraux, J., Nicks, B. 2011. Ammonia emissions from pig houses: Influencing factors and mitigation techniques. Ecosystems \& Environment, Vol. 141, Iss. 3-4, pp. 245-260. https://doi.org/10.1016/j.agee.2011.03.012

15. Rong, L., Nielsen, P.V., Zhang, G. 2009. Effects of airflow and liquid temperature on ammonia mass transfer above an emission surface: Experimental study on emission rate. Bioresource Technology, Vol. 100, Iss. 20, pp. 4654-4661. https://doi.org/10.1016/j.biortech.2009.05.003

16. Rzeźnik, W., Mielcarek, P., Rzeźnik, I. 2016. Pilot Study of Greenhouse Gases and Ammonia Emissions from Naturally Ventilated Barns for Dairy Cows. Polish Journal of Environmental Studies, Vol. 25, Iss. 6, pp. $2553-2562$. https://doi.org/10.15244/pjoes/63660

17. Saha, C.K., Zhang, G., Ni, J. Q. 2010. Airflow and concentration characterisation and ammonia mass transfer modelling in wind tunnel studies. Biosystems engineering, Vol. 107, pp. 328-340. https://doi.org/10.1016/j.biosystemseng.2010.09.007

18. Teye, F.K., Hautala, M., Pastell, M., Praks, J., Veermae, I., Poikalainen, V., Pajumagi, A., Kivinen, T., Ahokas, J. 2008. Microclimate and ventilation in Estonian and Finnish dairy buildings. Energy Buildings, Vol. 40, pp. $1194-1201$. https://doi.org/10.1016/j.enbuild.2007.10.017

19. Samer, M., Ammon, C., Loebsin, C., Fiedler, M., Berg, W., Sanftleben, P., Brunsch, R. 2012. Moisture balance and tracer gas technique for ventilation rates measurement and greenhouse gases and ammonia emissions quantification in naturally ventilated buildings. Building and Environment, Vol. 50, pp. 10-20.https://doi.org/10.1016/j.buildenv.2011.10.008

20. Zhao, L.Y., Bruger, M.F., Manuron, R.B. 2007. Variations of air quality of New Ohio dairy facilities with natural ventilation systems. Aplied Engineering in Agriculture, Vol. 23, Iss. 3, pp. 339-346.https://doi.org/10.13031/2013.22684

21. Wu, W., Zhang, G., Kai, P. 2012. Ammonia and methane emissions from two naturally ventilated dairy cattle buildings and the influence of climatic factors on ammonia emissions. Atmospheric Environment, Vol. 61, pp. $232-243$. https://doi.org/10.1016/j.atmosenv.2012.07.050 